\title{
The Political Ritual, the Party and the People: A Perspective on Sinicization of Marxism in the New Democratic Revolution*
}

\author{
Wei Fu \\ School of Marxism, Guangdong University of Foreign Studies, Guangzhou, China \\ Email: scutphdgdufs@hotmail.com
}

How to cite this paper: Fu, W. (2019). The Political Ritual, the Party and the People: A Perspective on Sinicization of Marxism in the New Democratic Revolution. Advances in Anthropology, 9, 1-12.

https://doi.org/10.4236/aa.2019.91001

Received: November 16, 2018

Accepted: December 16, 2018

Published: December 19, 2018

Copyright $\odot 2019$ by author and Scientific Research Publishing Inc. This work is licensed under the Creative Commons Attribution International License (CC BY 4.0).

http://creativecommons.org/licenses/by/4.0/

\section{(c) (i) Open Access}

\begin{abstract}
Marxism was not only a set of philosophical theory but also the ideology of the Party. The Sinicization of Marxism was a process in which the abstract principles of Marxism became the guiding ideology of the CPC under the specific practical environment of China. The Sinicization of Marxism was based on the combination of Marxism and the Party, the Chinese people, as well as that of Marxism and the revolutionary practice in China. In this process, political ritual as a part of the Party's ideology played an important role. And the practical experience of political ritual in the period of the new democratic revolution could give some inspiration to current and future ideological work.
\end{abstract}

\section{Keywords}

Political Ritual, Marxism, Sinicization, Ideology, the New Democratic Revolution

\section{Introduction}

Ritual was always performed by some people, under specific space-time conditions with certain prescriptive, symbolic means to express certain meaning. Political ritual was the combination of ritual thinking and behavior in the field of politics. Admittedly, there was some definition of political ritual in the existing academic discourse, such as "political ritual was one of many ritual types and a common political landscape in social life. It was a kind of action based on certain beliefs, with obvious power attributes and certain compulsory norms. What it

${ }^{*}$ Acknowledge: This Research Project (No. 2018JKSJD73) was supported by the Foundation of the 13th Five-Year Plan for Education Science of Guangdong Province. 
showed, conveyed or strengthened was a certain political significance" (Liao, 2008). But in this paper, the definition of "political ritual" was some ideological work of the party, which was held on the basis of certain cultural traditions and under specific space-time conditions for specific people, prescriptive and symbolic to a certain extent, aiming at producing beliefs. Marxism was not only a system which included philosophy, political economics and scientific socialism but also the guiding ideology of the Marxism political parties. As all we knew, Marxism was born in the West. Marxism came into being with the critique of capitalist society by intellectuals in capitalist society. Therefore, Marx and Engels recognized that great attention must be paid to make more people understand and accept Marxism. For example, at the beginning of "the first volume of Das Kapital", Marx put forward that the description and analysis of "value-in-commodity-theory" was the most difficult to understand. So, Marx suggested that the first chapter of the book be as popular and simple as possible by using simpler language so that it could be understood by ordinary people (Marx, 2012). During the period of the New Democratic Revolution, China was a typical oriental society. Due to historical and social reasons, the general educational level of the Chinese people at that time was not high. Therefore, for the ordinary Chinese people at that time, there were difficulties in understanding and accepting Marxism as their own thoughts. So, it was very urgent that Marxism must be combined with China's specific conditions. This process was the Sinicization of Marxism. One of the keys to Sinicization of Marxism lied in the combination of the theory and the practice in a certain way. And, the political ritual played an important role in this process. Obviously, political ritual promoted Sinicization of Marxism. This article was to show you the forms of political ritual in the Sinicization of Marxism and how they played their role.

\section{Political Ritual and the Political Party}

\subsection{The Political Ritual Performed on the Birth of the Party}

After a lot of preparatory work, the first National Congress of the Communist Party of China (CPC) was held on July 23rd, 1921 at No. 106 in Wang-Zhi Road, Shanghai. The meeting place was an old-style residential building on the street. It was the home of Li Han-jun, an early Party member of China (Figure 1).

In the middle of the living room there lied a rectangular dining table of western style. There were tea sets, vases and copper ashtray on it. Around the dining table, there were 12 round stools. What was different from a living room of an ordinary family was that the conference hall was full of solemnity seeing from the layout of the room, while it was not as grandiosity as other conference hall (Figure 2).

It was at the first National Congress that the birth of the CPC was announced. And, it also issued a series of important documents, such as "The First Program of the Communist Party of China" and "The First Resolution of the Communist Party of China". These documents stipulated some important political symbols 


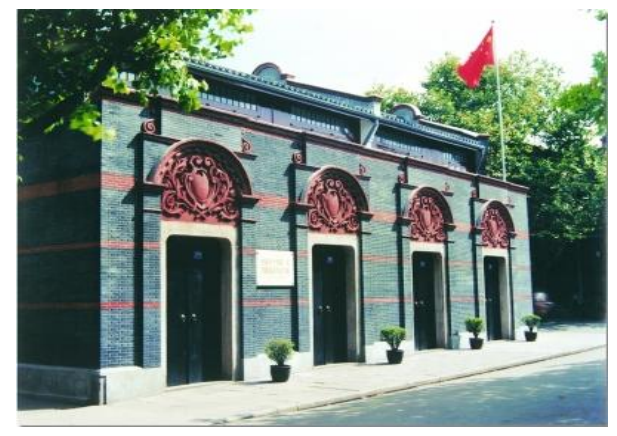

Figure 1. A snapshot of the site of the first National Congress of the CPC, provided by the Memorial Hall at the Site of the First Congress of the CPC.

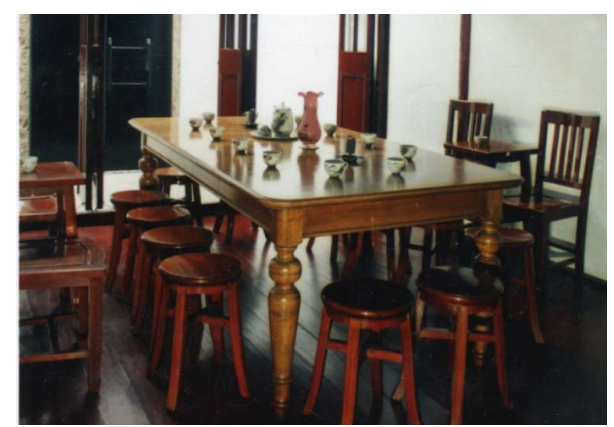

Figure 2. The inside scene of the site of the first National Congress of the CPC, provided by the Memorial Hall at the Site of the First Congress of the CPC.

such as the formal name of the party and her tasks. This political ritual not only announced the birth of the Party, but also explicitly regarded Marxism as the guiding ideology of the CPC.

\subsection{The Political Ritual and System Construction of the Party}

The system construction of the Party contained many sections. New member's initiation into the CPC was the act or process by which they officially became a party member, often involving special ceremonies. The ceremony that the new members' joining the Party embodied the thought about political party in Marxism. In the ritual of new member's joining the Party, the regulations on the system of "introduce", the system of "period of investigation" and that of "period of waiting" were put forward. These regulations had different requirements for people from different social backgrounds who wanted to join the Party. In the process of this ceremony, these regulations were strengthened to distinguish and select those new members.

In August 1925, the Central Committee of the CPC clearly stipulated the ritual of joining the Party in "Circular No. 53 of the Central Committee-the Alternative Measures for Introducing the New Party Members, Organizations and Tasks of the Party and the Communist Youth League in Various Groups". It told that the new applicants for joining the Party must go through the ceremony of join- 
ing the Party and be immediately incorporated into a branch (The Central Archive, 1989a). Under this provision, in some factories and schools where Marxism was deeply disseminated while the masses were well-educated and highly conscious, the "oath-taking ceremony" had been adopted and had gradually formed a certain procedure. Generally speaking, in party-joining ceremony at that time there must be a host for the meeting, at least one introducer, and the applicant for joining the Party. The whole process of the Party-joining ceremony could be summarized as the following steps: Party-joining talk; hanging Party flag; oath-taking. Before the start of the oath-taking, there must be a serious talk between the applicant and his or her introducer. Then the applicant took the oath of joining the Party under the hanging Party flay. It was said that the oath of joining the Party varies from time to time. At early times of the Party, the oath was "To obey discipline and sacrifice myself; to strive for revolution and class struggle; to keep secrets and never to betray the Party." After the failure of the Great Revolution, when the Party's work was in a state of secrecy, the work of recruiting new Party members had to be carried out under the condition of ensuring security. As a result, the ceremony of joining the Party became very simple. It was not until 1929 that the ceremony of joining the Party gradually took the road of standardization. In March 1930, the Party-joining ceremony was mentioned in particular in "Central Circular No. 73 - Recruiting Party Members from Industrial Workers to Strengthen the Proletarian Foundation of the Party". It said that the Party-joining ceremony should be held for the new Party members and that some preliminary education about the Party should be given (The Central Archive, 1989c).

Recruiting a large number of new members into the Party, of course, brought about some problems, such as how to ensure that the members who newly joined the Party were politically reliable and how to have a more effective selection. According to the records, a certain distinction was made between new members with different social background when came to the Party-joining ceremony." Party members who surrendered before must never resume their party membership"; "There must be a waiting period before applicants from petty bourgeoisie joining the Party. Having had serious investigation, they could become formal members of the Party". "In the Soviet region, the waiting-period-system which was to tell the difference from the regular Party members should be implemented. And, the necessary Communist training should be given to the new Party members". The Party had recognized that Party-joining ceremony be very necessary. "We must make the people feel that the difference between the mass social organization and the Party. For the Party is indeed the only leader in the mass revolutionary struggle, joining the Party is by no means a casual matter, but a matter of great responsibility and very honorable" (The Central Archive, 1989c). As for the outstanding members who were emerging from the revolution, the waiting period before they formally became Party members could also be omitted according to the regulations. 


\subsection{The Political Ritual and the Development of the Party's Guiding Ideology}

The Sinicization of Marxism required that the CPC learn to apply methods and principles from Marxism to solve the practical problem in the Chinese revolution. It meant that the CPC must choose the proper way for Chinese revolution. The political rituals of the form of conference always played an important role in the fight against the wrong views. At the famous August 7th-conference which was held in 1927, Mao Zedong put forward his well-known statement, asserting "the regime could only be achieved by the gun". And, the former General Secretary Chen Du-xiu and his rightist capitulationism were defeated at this conference. The Zun-Yi meeting held in 1935 ended the rule of Wang Ming and his leftist dogmatism in the Central Committee of the CPC. These conferences showed that the CPC applied Marxism to solve the practical problems in Chinese revolution. There was no doubt that those conferences saved the Party and the Chinese revolution. In October 1938, at the 6th Plenary Session of the 6th Central Committee of the CPC, Mao Zedong put forward the proposition of "Making the Marxism concrete in China". At the 7th Plenary Session of the 6th Central Committee of the CPC, Mao Zedong was officially declared the leader of the CPC, and Mao Zedong Thought the Sinicism of Marxism. From April $23^{\text {rd }}$ to June $14^{\text {th }}$ in 1945 , the 7 th National Congress of the CPC established Mao Zedong Thought as the guiding ideology of the Party. Having combed those historical materials, we would find that every progress of the Sinicism of Marxism was confirmed by political ritual. In a word, the political ritual marked the progress of Sinicism of Marxism.

\section{Political Ritual and the Progress of the Chinese People Accepting Marxism as Their Own Thought}

Facing the problem of propagating the Marxism among the grass-roots masses of China, the Party had to take into consideration the Chinese people's knowledge, culture level, their understanding ability and interest tendencies, so as to make the Marxism more easily understood and then accepted. Therefore, the political ritual with flexible and attractive external forms became an excellent working method.

\subsection{The Types of Political Ritual in the New Democratic Revolution of China}

The political ritual in the revolutionary could be divided into different types. First of all, judging from the scale, there were small ritual which took up shorter time and smaller space and large ritual which took up more. Sometimes, the ritual essentially the same showed different external scales. For example, there was a kind of famous political ritual performed in different periods of the Chinese revolutionary, called the "Grievance-Venting". As a kind of political ritual, it was performed to make the participants understand the root cause of their suffering 
deeply. The political ritual "Grievance-Venting" was performed during the ideological education for the poor peasants and captured enemy soldiers. Considering that most of the soldiers who were caught in the war were from the poor peasant class, the CPC believed that it was absolutely necessary to win over the soldier captured in these wars through ideological and political work. The CPC combined the participants' understanding of the revolution with their own survival and made the revolutionary thought of Marxism become their own, which would exert great power in the war of liberation.

In fact, according to the Selected Documents of Central Committee of the CPC, the history of "Grievance-Venting" (Li, 2008) could be traced back to the early days of the Party. Looking through these archival materials, it was found that in 1920s, the CPC had realized that the ideological and political work should begin with conceiving the agony of the soldiers. And imparting of knowledge about Workers-and-Peasants alliance, the land revolution, the Soviet State and so on was always established on the basis of the "Grievance-Venting". It was said that "the main way was always oral talk", and that "small propaganda was sometimes needed", "for the sake of seizing the belief of the enemy soldiers" (The Central Archive, 1989b).

In the liberation war of China in 1940s, because of the more powerful strength of the Party and the development of the favorable situation of the revolution, the extensive struggle for the revolutionary masses had also become an important task at that time. Therefore, it was not necessary to take the secret form. As a result, the "Grievance-Venting" could be held open, taking more time and bigger space. This kind of ideological work seemed to be very similar to the one held in the period of Revolutionary War in China, 1920s. The subtle difference between them lied in the "social accessibility", a parameter which was used to measure the openness of the activity to the public. That was to say, Grievance-Venting, as a kind of political ritual, could only be held under a secret or private environment, as a result of the serious "White terror" of the reactionaries. So, at that time, the Central Committee of the CPC had to carry out the ideological work "without the form of ritual", and "not to record it". All the matters related to the revolution, could only be "kept in mind" as well as "conveyed only by mouth". Only in this way, "could the secret of the Party be kept" (The Central Archive, 1989b).

Ritual came from life, so political ritual certainly inherited the diversity of social life and then had many external forms. We could see from archival materials that there were many types of political ritual held by the CPC in history, such as meetings, assemblies, commemorations, ceremonies, festivals and so on.

Whether modern or not, all kinds of ritual were applied to the daily life to propagandize and teach Marx's doctrine. Daily life was trivial. The CPC came to recognize that the dissemination of revolutionary ideas required not only political slogans, but also the combination of revolutionary ideas and concrete issues in daily life. 
In the revolution, the CPC held the ritual which came from daily life and were certainly familiar to the people, such as the fairs in the countryside, various festivals, folk games, and so on. As a result, the abstract of Marx's doctrine was transformed into concrete. This way enabled the masses to understand profound revolutionary ideas on the basis of their own knowledge level and cognitive ability.

These kinds of political ritual were concerned not only with the material interests of the people, but also with the spiritual interests such as dignity, honor, and so on. As proposal by Maslow's demand level theory, human needs are hierarchical and diverse, such as demand for food and clothing, security, social interaction, dignity, and so on (Wahba \& Bridwell, 1976). Actually, the aim of the new democratic revolution of China was to overthrow the tyrants and to distribute the land. There was always a political ritual in the process of "overthrowing the tyrants and distributing their land". In this process, there must be a place in which the landlord captured knelt down, listening to the guilt that was accused of by the poor peasants (Li, 2008). The result of such a political ritual not only made the poor peasants obtain some land and other production materials, but also brought the decline of the political status of the landlord class.

\subsection{Strong Correlation between Political Ritual and Chinese Tradition}

When discussing the issue of ideology, Karl Marx especially emphasized the dependence of ideology on "tradition" as a superstructure of ideas. He believed that the economic foundation decided the superstructure. Therefore, in realistic social life there were various different and unique emotion, fantasy, ways of thinking and outlook on life, which prescribed the ideology tradition of a particular society (Marx, 2009). Therefore, when we discussed the process of Sinicization of Marxism, Chinese tradition must be taken seriously. Ritual played an important role in Chinese traditional economic basis, Chinese traditional political basis as well as Chinese traditional social relationship basis. It was political ritual that led to an effective way of the Sinicization of Marxism.

Firstly, from the perspective of the economic basis of traditional Chinese society, the economic form dominated by farming provided the basis for the existence and development of ritual. According to Marx and Engels' generalization of the characteristics of "Asian mode of production", the main economic mode of production was crop cultivation in the region of the Great River Basin. Therefore, people engaged in agricultural production arranged their work and life according to seasonal climate change and the law of the periodic growth of crops. This regularity and repetition affected other fields of people's daily life through economic production of the whole society, and had an impact on diet, toilet, utensil production, sacrifice, worship and entertainment. In these activities, some prescriptive things were adhered to. They played important roles in people's mind. As a result, they came to guide people's practice. Then, they became kinds of ritual. 
Secondly, in areas where farming was the main mode of economic production, the conditions to provide security for production, such as large-scale water conservancy facilities, needed to organize individual workers engaged in agricultural production and played a cooperative role. The process of transformation from individual to collective often needed to be realized through ritual. Moreover, there was no complete sense of land private ownership in eastern society. In this case, the collective as a whole became the supreme community of individual existence, and the surplus products obtained in production were often used to praise the supreme community (Marx, 1979). Actually speaking, "praising" was a sacrificial ritual that had influenced China for thousands of years.

Thirdly, traditional Chinese social relations structure was often expressed through "ritual". Because the long-standing existence of rural communes was combined with agriculture and family handicraft industry, the traditional oriental society developed patriarchal relationship. Anthropologist Fei Xiao-tong summed up the traditional structure of Chinese society as a pattern of "Difference-Sequence". It looked like throwing a stone into the water, and the center of the stone falling into the water would be rippled from inside to outside. Around a center, people's close or distant relationships were gradually pushed forward in a hierarchical order, just like the ripples in this circle (Fei, 2008). Close relationship was reflected in daily rituals, especially in "sacrifices" and "sworn" activities. Rituals were based on the patriarchal clan and constructed different levels of society through moral enlightenment, self-discipline of rules and heteronomy. And through the holding of ritual, the ideas it contained were gradually imperceptible to every member of society in this structure.

For the three reasons above, in the process of combining Marxism with Chinese tradition, the application of ritual, especially the transformation and utilization of traditional ritual forms in the context of actual work, became an inevitable theme. It included the following aspects: The symbols used in ceremonies should be based on traditional thinking as much as possible; The creation of these symbols, including the selection and use of color, shape, pattern, discourse should maintain consistency with traditional Chinese practices; Organizations and ritual that existed in society for a certain period of time and reflected certain traditions, such as the Red Gun Club, the Big Sword Society, the Brotherhood Club, should be utilized so as to carry out work according to people's ideological conditions at that time. Then the revolutionary power could be united; As to Some traditional ceremonial activities, such as "local ballads", "dramas", traditional festivals, celebrations, ceremonies and gatherings, it was necessary to "make the best use of them" because of their popular forms. It was necessary to rely political ritual to grasp the opportunity of ideological work for the masses well (The Central Archive, 1991).

It should be pointed out that the application of traditional political ritual held by the CPC in the process of combining Marxism with Chinese tradition was the sublation of tradition. Actually, inheritance of tradition was not acceptance 
without choice, but selective inheritance and utilization. The standard of choice was to see whether these traditional forms embodied the thinking of the masses of the grass-roots society, whether they could promote the development of the revolutionary situation, whether they widely mobilized social resources.

\section{Conclusion}

The process of combining Marx doctrine with Chinese revolution was a process of mutual promotion between theory and practice. As an externalization of ideology, political ritual played important roles in such two aspects:

On one hand, Marxism was tested by practice in the process of guiding Chinese revolution. And, the holding of political ritual provided opportunities for testing segmental results. In the early period of the combination of Marxism and the Chinese revolution, the Chinese revolution was misled by some wrong ideas, so it was once at a very critical juncture. Let's return to the example we mentioned earlier in this article, the fifth anti-encirclement-and-suppression campaign suffered a tragic failure in 1934 because of the errors of Bo Gu, the leader of the $\mathrm{CPC}$ at that time, and $\mathrm{Li} \mathrm{De}$, the representative of the Communist International. The Zun-Yi Meeting was held on the long march. At the Zun-Yi Meeting, those wrong ideas of Leftist adventurism were criticized. Mao Zedong had long been aware of the existence of erroneous ideological tendencies such as dogmatism, and had clearly pointed out that the development of the Chinese revolution depended on Chinese comrades themselves. They must analyze the situation of Chinese revolution correctly and abandon the negative influence of dogmatism. However, this correct opinion was not adopted by the Political Bureau of the CPC at that time, nor was there a suitable opportunity for all the comrades to recognize it. When the Central Red Army marched to Zun-Yi, a very remote town, they lost contact with the Communist International because of problems in telecommunications facilities. There came a favorable opportunity for holding of a meeting aiming at getting rid of such influences as the Dogmatism, the sanctification of the revolutionary experience of the Soviet Union and other erroneous ideas. In this purposeful political ritual, erroneous ideas and their spokesmen could not play a role (Li, 1983). Mao Zedong and other comrades who independently analyzed and summarized the experience and lessons of the Chinese revolution with the methods of Marxism gained the leadership of the CPC. The periodic achievements of the combination of Marxism and Chinese revolution were confirmed and fixed through political rituals, which enabled it to guide China's revolutionary practice justly, so that to save the Party, the Red Army and the Chinese revolution. In this process, political rituals not only ensured the success of ideological struggle, but also displayed the victory in the field of armed struggle, and publicized the political power achieved through ideological victory.

On the other hand, the guidance of Marxism to the Chinese revolution was also embodied in the analysis of the characteristics of the Chinese revolution 
with Marxist ideological methods. And, the political ritual was the form of carrying out the revolutionary work in accordance with these characteristics. Unlike the revolutionary road of the Soviet Union, China in the semi-colonial and semi-feudal society chose a very different revolutionary road. In Chinese revolution, the countryside would be seized before capturing the city. Therefore, rural areas and farmers became the most important force on which the CPC could rely. Mao Zedong and other party leaders repeatedly emphasized that peasants should not be ignored in China. In rural areas, the peasants-work could not be divorced from the reality of farmers. And, adopting some ritual forms to carry out ideological and political work was the most flexible strategy. For example, the $\mathrm{CPC}$ recognized that as long as the most primitive and superstitious organizations in the countryside were somewhat revolutionary, it would be necessary to find ways to raise their awareness through ideological work, and to find ways to absorb some members of these organizations into the revolutionary ranks (The Central Archive, 1991). The CPC invited some members of these organizations to take part in struggle. So there required a sense of identity of those who were united. This sense of identity could be carried out through traditional ritual forms which were recognized by rural society. First, they became friends or good guys with each other through transitional ceremony. And, in the process of becoming more and more familiar with each other, the original members of those superstitious organizations were educated about revolutionary ideas. Then, some of them would be accepted as members of the CPC if necessary. Those party members separated themselves from the reactionary elements when joining the Party through transitional ceremonies and became the power of the revolution.

Generally speaking, as an externalized part of ideology, the political ritual, which was applied to the combination of Marxism and the concrete practice of Chinese revolution, had also been developed in this process. This development, in turn, promoted the Sinicization of Marxism and embodied the interactive relationship between Marxist ideology and Chinese revolution. The purpose of ideological work was to set up relevant beliefs for the people. Belief system was composed of a series of images, which constituted a complete individual world. They were all-encompassing, with both past and present perspectives, expectations of future possibilities and value orientations that should be based on (Russett \& Starr, 2001). That was to say, ideological work not only provided the world with an interpretation system for scientific knowledge, but also a set of symbolic system for emotion and value. Symbols, as cognitive tools of human beings, could not explain problems and express emotions independently. To play a directive role in emotion and value, symbols system should be in the practice, which always took the form of political ritual. As an ideological work, political ritual would not be less and less, but more and more in modern society. After all, this was a world full of meaning. There should be more ways to express what we wanted to express. We inherited many ritual forms associated with traditional society, such as festivals, sacrifices, celebrations, gatherings and so on. We also should create many other forms of ritual which could be applied in social and 
political life. Therefore, the CPC's experience on political ritual in the period of new democratic revolution was still of great value.

\section{Epilogue}

1) Studying the Sinicization of Marxism from the perspective of "political ritual" not only came from my own learning experience and academic interest, but also from the practical requirements of work.

2) Unlike anthropologists, my researched on "political ritual" mainly relied on literature. To study this issue, I had read the main documents of the CPC from 1921 to 1949. However, the abundant literature foundation of this research still could not make up for the lack of field investigation in this paper.

3) Ritual was a form of activity. To carry out ideological work by means of ritual thinking and behavior was not to equate with the practice of formalism. Limited by the layout of the article, this paper did not discuss the relationship between political ritual and formalism in ideological work.

4) The mechanism of the effect of political rituals on people's ideological world needs further study.

\section{Conflicts of Interest}

The author declares no conflicts of interest regarding the publication of this paper.

\section{References}

Fei, X.-T. (2008). From the Soil: The Foundations of Chinese Society (pp. 25-34). Beijing: People's Publishing House.

Li, A.-B. (1983). Zun-Yi Meeting: The Great Victory of Marxism Combined with the Concrete Practice of Chinese Revolution. History Teaching, No. 12.

Li, Y. (2008). The Emotional Mobilization in Chinese Revolution: On the "Suku" and "Fanshen" in the Land Reform from 1946 to 1948 in North China. Unpublished Master's Dissertation, Fudan University, Shanghai, China.

Marx, K. (1979). Collected Works of Marx and Engels (Book 1 of Vol. 46, pp. 473). Beijing: People's Publishing House.

Marx, K. (2009). Anthology of Marx and Engels (pp. 498). Beijing: People's Publishing House.

Marx, K. (2012). Selected Works of Marx and Engels (pp. 81). Beijing: People's Publishing House.

Russett, B., \& Starr, H. (2001). World Politics. Beijing: Hua-Xia Publishing House.

The Central Archive (Eds.) (1989a). The $1^{\text {st }}$ Volume of Selected Documents of the CPC Central Committee (1921-1925) (pp. 93-95). Beijing: CPC Central Committee Party School Press.

The Central Archive (Eds.) (1989b). The $4^{\text {th }}$ Volume of Selected Documents of the CPC Central Committee (1928) (pp. 228, 500, 415-416, 600-601). Beijing: CPC Central Committee Party School Press.

The Central Archive (Eds.) (1989c). The $6^{\text {th }}$ Volume of Selected Documents of the CPC Central Committee (1930) (pp. 54, 194, 326). Beijing: CPC Central Committee Party School Press. 
The Central Archive (Eds.) (1991). The $13^{\text {th }}$ Volume of Selected Documents of the CPC Central Committee (1941-1942) (pp. 162, 342). Beijing: CPC Central Committee Party School Press.

Wahba, M. A., \& Bridwell, L. G. (1976). Maslow Reconsidered: A Review of Research on the Need Hierarchy Theory. Organizational Behavior and Human Performance, 15, 212-240. https://doi.org/10.1016/0030-5073(76)90038-6 